\title{
Examining Indonesian Secondary School Mathematics Teachers' Instructional Practice in the Integration of Technology
}

\author{
Mailizar Mailizar ${ }^{1, *}$, Lianghuo Fan ${ }^{2,3}$ \\ ${ }^{1}$ Department of Mathematics Education, Universitas Syiah Kuala University, Indonesia \\ ${ }^{2}$ Asian Centre for Mathematics Education, East China Normal University, China \\ ${ }^{3}$ Southampton Education School, University of Southampton, Southampton, UK
}

Received June 24, 2020; Revised August 10, 2020; Accepted August 25, 2020

\section{Cite This Paper in the following Citation Styles}

(a): [1] Mailizar Mailizar, Lianghuo Fan, "Examining Indonesian Secondary School Mathematics Teachers' Instructional Practice in the Integration of Technology," Universal Journal of Educational Research, Vol. 8, No. 10, pp. 4692-4699, 2020. DOI: 10.13189/ujer.2020.081038.

(b): Mailizar Mailizar, Lianghuo Fan (2020). Examining Indonesian Secondary School Mathematics Teachers' Instructional Practice in the Integration of Technology. Universal Journal of Educational Research, 8(10), 4692-4699. DOI: 10.13189/ujer.2020.081038.

Copyright $\bigcirc 2020$ by authors, all rights reserved. Authors agree that this article remains permanently open access under the terms of the Creative Commons Attribution License 4.0 International License

\begin{abstract}
The Indonesian secondary school mathematics curriculum advocates the use of technology in teaching and learning of mathematics. The previous studies paid less attention to what type of digital tools that the teachers used and how they integrated them in the mathematics teaching. This study aimed at investigating Indonesian secondary school mathematics teachers' instructional practices in the integration of digital technology in classrooms and examined differences in teachers' instructional practice according to their background. It employed a quantitative approach whereby were collected through a questionnaire survey. The data were gathered from 341 mathematics teachers in 93 secondary schools. This study suggested that the integration of digital technology has emerged in Indonesian secondary school mathematics classrooms. However, it was also found that most of the teachers did not use the technology in constructive ways. The result also revealed that female teachers have better instructional practices in the use of digital technology than male teachers. In addition, teachers' levels of education play an important role on their instructional practices with digital technologies. This study suggests that it needs a radical improvement of the integration of technology in Indonesian secondary school mathematics classrooms in order to achieve the curriculum objective. Therefore,
\end{abstract}

further research and development on this issue is needed in the country.

Keywords ICT in Teaching, Teacher Classroom Practice, Indonesian Mathematics Education, Technology in the Mathematics Classroom

\section{Introduction}

According to Mailizar, Manahel [1], in 1984, the Indonesian government introduced the first curriculum that stipulated the integration of modern technologies into teaching and learning of mathematics. Furthermore, the Indonesian current curriculum stipulates the integration of digital technology in the teaching and learning process. It is revealed in the curriculum document: "In order to improve the effectiveness of teaching and learning, schools should promote the integration of technology such as computer and other media (p. 397)".

Previous studies $[2,3]$ indicate technology integration in the classroom is a complex process and does not depend only on technology-related factors. Technological tools such as computer and tablets, do not direct teachers' pedagogical approach [4]. This is in line with Hardman [5] 
and Jackson [6], arguing that the impact of technology use in teaching depends on teachers' pedagogical practices.

Ottenbreit-Leftwich, Kopcha [7] conducted a literature review and revealed that teachers, integration of technology has been investigated in various ways such as the frequency use of technology and student-centred and teacher-centred teaching practices with technology. In mathematics education, a number of studies have also been carried out around the world aimed at investigating the use of technology in teaching of mathematics emphasizing at different aspects such as teaching approaches [e.g., 8, 9] and types of technologies [e.g.,10, 11-14]. Other researchers examined pedagogical approaches in the use of technology [e.g., 14, 15, 16-22]. Also, previous studies have also measured the frequency of technologies use in the mathematic classroom [e.g., 8].

A limited number of studies have investigated the integration of digital technologies in mathematics classrooms in Indonesia. Most of them are part of international studies [e.g., 23, 24]. Mullis, Martin [23], for instance, showed that $16 \%$ of students in Indonesian secondary school had access to digital tools in mathematics classrooms. In 2011, Mullis, Martin [24] revealed that the number had increased significantly that $87 \%$ of mathematics at least one computer for at least one student. They also revealed Indonesian mathematics teacher's frequency use of computers for exploring principles and concepts of mathematics and searching information and idea. However, the previous studies on Indonesian secondary school mathematics teachers' integration of digital technology paid less attention to what type of digital tools being used and how the teachers integrated them in mathematics classroom. For example, Mullis et al.'s [24] study did not reveal pedagogical activities regarding the integration of digital technology. In addition, there has been no study in Indonesian that uses Pierce and Stacey's (2010) Mathematics Analysis Software (MAS) pedagogical map to advance our understanding of the teachers' instructional practice in the integration of digital technology.

This study aimed at investigating Indonesian mathematics teachers' instructional practices in the implementation of digital technology and examining their instructional practices based on to their background. Hence, we sought to respond to these research questions:

1) To what extent do Indonesian secondary school mathematics teachers integrate digital technology in their classrooms?

2) Is there any significant difference in Indonesian secondary school mathematics teachers' instructional practices in the integration use of digital technology according to their demographic background?

\section{Conceptual Framework}

The effectiveness of technology integration in the teaching and learning process depends on teachers' instructional practices [25]. Further, it also depends on how teachers select and manage resources of technology into their classroom activities as what instructional strategies they integrate in the classroom. Secondary school teachers' integration of technology has been investigated in many countries in which researchers looked at various aspects of the integration and employed different conceptual frameworks to understand it.

Previous studies have used various framework and approaches to understand teachers' use of digital technologies. The frameworks that have been used such as the student-centred and teacher-centred [e.g., 8, 14, 18, 19]; the Learning with and Learning from [e.g., 17]; routine, extended and innovative user [e.g., 15]. Regarding studies of mathematics teacher of the technology, Pierce and Stacey [26] proposed the pedagogical map of MAS framework explaining instructional opportunities offered by MAS. MAS is software that users can conduct many activities such as arithmetic calculations, statistics calculations, data visualization, algebra manipulations. Pierce and Stacey [26] structured three level of the pedagogical map of MAS, namely, the tasks level, classroom level and subject level.

In this study, we adapted Piece and Stacey's [26] pedagogical map to explain the mathematics teachers' instructional practices in the integration of digital technologies in the classroom. This framework provides relatively comprehensive aspects to examine technology integration in mathematics classrooms. Therefore, we investigated two aspects, namely, type of technologies and functional and pedagogical activities.

\section{Methods}

\subsection{Design of the Study}

We used a quantitative approach with the cross-sectional survey design. According to Creswell [27], the survey can be used to collect data concerning participants' opinions, perceptions, and practices. Hence, in this study, we collect data on instructional practices of Indonesian secondary school mathematics teachers in the integration of digital technology.

\subsection{Participants and Settings}

We employed a stratified random sampling technique to draw a representative sample as the technique increases data representative [28]. To acquire a large sample size, we distributed the questionnaire in 93 Schools from 16 regencies/cities. A total of 355 questionnaires were filled, and 14 of them were incomplete. Therefore, it left 341 questionnaires for the analysis. Participants' demographic backgrounds are provided in Table 1. 
Table 1. Demographic profile of participants

\begin{tabular}{|c|c|c|}
\hline \multicolumn{2}{|c|}{ Demographic Profile } & $\begin{array}{c}\text { Frequency } \\
\text { (Percentage) }\end{array}$ \\
\hline \multirow{4}{*}{ Gender } & Male & $213(62.6 \%)$ \\
\cline { 2 - 3 } & Female & $128(37.4 \%)$ \\
\hline \multirow{4}{*}{$\begin{array}{c}\text { Teaching Experience } \\
\text { (Year) }\end{array}$} & Over 30 & $58(16.9 \%)$ \\
\cline { 2 - 3 } & $21-30$ & $93(27.2 \%)$ \\
\cline { 2 - 3 } & $11-20$ & $76(21.9 \%)$ \\
\cline { 2 - 3 } & $6-10$ & $82(24.6 \%)$ \\
\hline \multirow{3}{*}{ Education } & $1-5$ & $32(9.5 \%)$ \\
\cline { 2 - 3 } & Master & $29(8.6 \%)$ \\
\cline { 2 - 3 } & Bachelor & $310(90.8 \%)$ \\
\hline
\end{tabular}

\subsection{Research Instrument}

In this study we developed a questionnaire for the conceptual framework and existing studies. As mentioned earlier, regarding teachers' instructional practices, we looked at types of technologies and teachers' classroom activities with technologies We developed a survey instrument to investigate the type of digital tools being used, and instructional activities with ICT. Some survey items were adopted from Law, Pelgrum [16]. All survey items were scored in a 5 -point scales from $1=$ never to $5=$ always.

\subsection{Reliability and Validity}

To assess reliability of the questioner, we used the internal consistency reliability. The inter-item correlation was examined through coefficient of Cronbach's alpha [29]. The data showed a high alpha coefficient of .968. In terms of the validity of the questionnaire, we evaluated the construct validity. Furthermore, we employed the confirmatory factor analysis to assess whether the items measure the construct accordingly. According to Muijs [29], factor loadings can show a correction between items and the overall factor. Results of this analysis produced .924 of the scale values, which fell into the range of being superb. Eigenvalues of all the five factors are 18.6, $2.4,2.2,1.4$, and 1.1. In addition, $69.6 \%$ of the total disparity was described by those factors. In addition, Factor loadings for this scale ranged from .490 to $.786, .492$ to $.868, .660$ to $.778, .462$ to .847 , and .460 to .742 , which indicate high factors loading.

\subsection{Data Analysis}

We employed analysis descriptive and inferential statistics to analyse the data. s. We calculated means and standard deviations of all the items. Furthermore, we conducted a repeated measure ANOVA as well as a paired t-test to examine differences across survey items. In addition, Kruskal Wallis and Mann Whitney tests were run to examine teachers' instructional practices according to teachers' demographic background.

\section{Results}

We present results of based on the research questions. First, we provide results of teacher classroom practice which is followed by results of differences in teachers' instructional practices in the integration of digital technology according to their background.

\subsection{Description of Teachers' Classroom Practices}

The results showed that $67.7 \%$ of the participants had at least once used digital technology in their mathematics classrooms. Unfortunately, $47.8 \%$ of the participants integrated the technology in $21 \%$ to $50 \%$ of their mathematics lessons. We present further detailed results on teachers' use of hardware and software, and teachers' functional and pedagogical activities when they used ICT in the classroom as follows.

\subsubsection{Teachers' Use Digital Tools}

Results of the frequency of secondary mathematic teachers' use of digital tools the classroom are shown in Table 2.

Table 2. Results of teachers' use of digital tools in the mathematics classroom

\begin{tabular}{|c|c|c|c|}
\hline \multicolumn{2}{|r|}{ ICT Use } & \multirow{2}{*}{$\frac{\text { Mean }}{2.5}$} & \multirow{2}{*}{$\begin{array}{r}\begin{array}{r}\text { Std. } \\
\text { Dev. }\end{array} \\
.99\end{array}$} \\
\hline \multirow{3}{*}{ Hardware } & Handheld Devices & & \\
\hline & Computers & 3.4 & .81 \\
\hline & Calculators & 2.2 & 1.16 \\
\hline \multirow{5}{*}{$\begin{array}{l}\text { General } \\
\text { Software }\end{array}$} & Word processor software & 3.1 & 1.09 \\
\hline & Presentation software & 3.3 & .97 \\
\hline & Spreadsheet software & 2.7 & 1.06 \\
\hline & Software of concept mapping & 1.7 & .89 \\
\hline & 3D software & 1.6 & .80 \\
\hline \multirow{3}{*}{$\begin{array}{l}\text { Mathematica } \\
1 \text { software }\end{array}$} & $\begin{array}{c}\text { Software of Computer } \\
\text { Algebra System }\end{array}$ & 1.8 & .98 \\
\hline & $\begin{array}{c}\text { Software of dynamic } \\
\text { mathematic and dynamic } \\
\text { geometry }\end{array}$ & 2.1 & 1.00 \\
\hline & Software of Statistic & 1.8 & .98 \\
\hline \multirow{2}{*}{$\begin{array}{l}\text { Online } \\
\text { Resource }\end{array}$} & Online teaching resources & 2.0 & 1.06 \\
\hline & LMS & 1.8 & 1.02 \\
\hline
\end{tabular}

We employed the repeated-measures ANOVA to examine differences in teacher's instructional practices. The results showed that teachers' use of hardware $(p=0.00)$ were significant differences across the hardware category. It also revealed their integration of general software $(p=$ $0.00)$ and mathematical software $(p=0.00)$ were significant differences across the mathematical software categories. Furthermore, a paired t-test was carried out to 
assess differences in teacher's integration of online teaching and learning resources. The results revealed that teachers' use of online resources $(p=0.00)$ and LMS $(p=$ 0.00 ) had significant differences.

\subsubsection{Functional and Pedagogical Activities with technologies in the mathematics classroom}

We also investigated teachers' functional and pedagogical activities when they used digital technology in the mathematic classroom. Survey results of teachers' functional and pedagogical activities with ICT in mathematics classroom are illustrated in Table 3 .

We conducted the repeated-measures ANOVA to examine differences of teacher's functional and pedagogical activities with digital technologies. There were significant differences in teachers' functional activities $(p=0.00)$ with digital technologies. The results also showed significant difference in teachers' pedagogical activities $(p=0.00)$, mathematics topics being taught $(\mathrm{p}=0.00)$, and tasks being set by the teachers $(p=0.01)$. Furthermore, in term of teachers' teaching approaches, results of a paired t-test revealed that teachers' use of digital technology to support teacher-centered approach and the student-centered approach was not significant difference with $\mathrm{p}=0.51$.

\subsubsection{Teachers' Instructional Practice According to Their Background}

We used Mann-Whitney and Kruskal-Wallis tests to assess differences in teacher integration of digital technologies according to their backgrounds. Table 4 and Table 5 present the results of Mann-Whitney as well as Kruskal-Wallis tests respectively. In addition, Table 6 highlights the results from both tests.

Table 3. Results of teachers' activities with digital technologies in the classroom

\begin{tabular}{|c|c|c|c|}
\hline \multicolumn{2}{|c|}{ Activities in the integration of digital technology in the classroom } & Mean & Std. Dev \\
\hline \multirow{6}{*}{ Functional activities } & Doing arithmetic activities & 3.1 & .91 \\
\hline & Drawing and plotting graphs of functions & 3.0 & 1.03 \\
\hline & Solving problems & 2.9 & 1.16 \\
\hline & Constructing diagrams & 3.0 & 1.23 \\
\hline & Doing computation and calculations & 2.8 & 1.16 \\
\hline & Creating 3Dobjects & 2.7 & 1.22 \\
\hline \multirow{6}{*}{ Classroom activities } & Giving mathematics classroom instructions & 2.8 & 1.10 \\
\hline & Presenting content of mathematics in the classroom & 2.8 & 1.11 \\
\hline & Conducting assessments & 2.3 & 1.06 \\
\hline & $\begin{array}{l}\text { Guiding student in mathematical exploratory and inquiry } \\
\text { activities }\end{array}$ & 2.4 & 1.07 \\
\hline & Providing feedback in learning mathematics & 2.4 & 1.15 \\
\hline & Providing remedial in learning mathematics & 2.3 & 1.13 \\
\hline \multirow{2}{*}{ Teaching approach } & Teacher-centred methods & 3.0 & .90 \\
\hline & Students-centred methods & 3.0 & .98 \\
\hline \multirow{5}{*}{ Subject } & The content of Geometry & 2.8 & .99 \\
\hline & The content of Calculus & 2.5 & 1.07 \\
\hline & The content of Trigonometry & 2.6 & 1.03 \\
\hline & The content of Algebra & 2.6 & 1.01 \\
\hline & The content of Statistics and Probability & 2.8 & 1.03 \\
\hline \multirow{5}{*}{ Task } & Learning pen-and-paper skills & 2.5 & 1.15 \\
\hline & Exploring regularity and variation & 2.4 & 1.10 \\
\hline & Linking representation & 2.4 & 1.08 \\
\hline & Simulating real situation & 2.4 & 1.10 \\
\hline & Using real data & 2.6 & 1.11 \\
\hline
\end{tabular}


Table 4. Results of Mann-Whitney test

\begin{tabular}{|c|c|c|c|}
\hline Variable & \multicolumn{2}{|c|}{ Median of Each Category } & P \\
\hline Gender & Male $=2.0$ & Female $=3.0$ & .006 \\
\hline
\end{tabular}

The results show male and female teachers' use of digital technology were statistically significantly different, indicating female (3.0) was better than male (2.0) with $\mathrm{p}=.006$.

Table 5. Results of Kruskal Wallis test

\begin{tabular}{|c|c|}
\hline Variables & Values \\
\hline Education Level & $\begin{array}{l}\text { H-Value }=7.1 ; \mathrm{df}=2 ; \text { Significant. }=.029 ; \\
\text { Mean Rank = Post-Sec. }(53.5) \text {; Undergrad. } \\
\text { (165.9); and Post-Grad. }(202.8)\end{array}$ \\
\hline $\begin{array}{c}\text { Teaching } \\
\text { Experience }\end{array}$ & $\begin{array}{l}\text { H-Value }=3.0 ; \mathrm{df}=4 ; \text { Significant. }=.55 ; \\
\text { Median }=2.0(1 \text { Years-5 Years }) ; 2.0(6 \\
\text { Years-10 Years }) ; 2.0(11 \text { Years-20 Years }) \\
(2.0) ; 2.0(21-30 \text { Years }) ; 1.0 \text { (Over } 30 \text { Years })\end{array}$ \\
\hline
\end{tabular}

The results suggested there were statistically significant differences in mathematics teachers' instructional practices according to gender of the participants and their education level. The teachers with a post-graduate degree had better instructional practices with digital technologies than teachers with other lower level degrees. Moreover, female teachers had better instructional practices with the technologies than male teachers.

Table 6. Summary of the results

\begin{tabular}{|c|c|}
\hline Demographic Background & Results \\
\hline Gender & Significant \\
\hline Level of Education & Significant \\
\hline Teaching Experience & Not Significant \\
\hline
\end{tabular}

\section{Discussion}

This study investigated Indonesian secondary school mathematics teachers' instructional practices in the integration of digital technology in teaching and learning of mathematics and examined differences in their practices according to demographic background. It was conducted in Indonesian that involved 341 secondary mathematics teachers as participants of the study. The findings of this study show several important points of discussion.

First, this study showed that $68 \%$ of the mathematics teachers in Indonesian have at least once used digital technologies in their classrooms yet they use it for the teaching of a limited number of lessons. This indicates a large numbers of secondary school mathematics teachers in Indonesia did not implement the policy on the integration of digital technology and did not fully implement the current curriculum stipulating the integration of digital technologies in the teaching and learning.

Second, the Indonesian secondary school mathematics teachers dominantly used presentation-oriented tools such as PowerPoint. This finding is in agreement with previous studies in other countries [e.g., 10,11, 14, 18]. It indicates that teachers did not take advantages of the digital tools that are specifically designed for teaching and learning of mathematics. In mathematics classroom, the use of presentation-oriented software such as PowerPoint does not provide many advantages in teaching of mathematics. Presentation-oriented software is not equipped with features that can facilitate students' knowledge construction and support them to work on rich mathematical tasks. Furthermore, this study showed the teachers mostly used GeoGebra software. GeoGebra was the most popular software over other mathematics software because it is free software that has been used widely around the world [see. 30] and accommodates the teaching and learning of a various mathematics topics such as Algebra, Geometry, and Statistics.

Third, doing arithmetic activities and drawing as well as plotting graphs of functions were the two most dominant activities exhibited in the mathematics classroom. The existing literature revealed mathematical graphing software was the earliest computer technologies developed for educational purpose [see 31]. It relates to the finding showing that software that allow users to easily plot graphs was the most frequently used mathematical software. Furthermore, presenting contents of mathematics was another common teachers' classroom activity when they integrate technology. This finding indicates that teachers did not commonly use technologies for conducting constructive activities such as inquiry activities.

Fourth, at classroom level, the teacher-centred approach was more dominant compared to the student-centred approach. This is in agreement with existing studies [e.g., 8, $9,19,20,32]$, showing that the integration of technology did not support student-centred instruction. Even in developed countries such as England where most of teachers still adopted teacher-centred practices when they used technology [see 14]. At the task level, most of the teachers used digital technologies as a tool for drill and practices. Cavanagh and Mitchelmore [33] argue that drill and practice tasks do not significantly affect students' learning outcomes since they are similar to rote learning exercises. In addition, at the subject level, this study showed that teachers commonly used technologies when they taught and they still approached mathematics topics in traditional ways such as starting a lesson by introducing a concept of mathematics which if followed by showing examples of mathematical problems and assigning students to complete them. This indicates that the mathematics teachers did not take advantages of building metacognition and overview of mathematics topics when they taught them. The literature [e.g., 34] highlights that higher-level thinking may be enhanced through the integration of technology if the teacher takes the opportunity to encourage metacognition and overview in learning of mathematics. Furthermore, the teachers did not change the balance between skills, concepts, and applicationsof 
mathematics. On the other hand,existing literature has showed that digital technology can help teachers to shift balance from learning facts to support students' argumentation [35].

Fifth, regarding differences in teacher use ICT according to their background, the study revealed that female teachers more frequently used technologies than male teachers. This finding contradict with the common view that technology-related activities have been seen as a "male domain'[43, 44, 46, 47]. However, regarding the integration of technology in the classroom, the domination of male teachers over female teachers is no longer exist. For instance, King, Bond and Blandford [48] and North and Noyes [49] claimed that technological competencies is no longer seen as a male dominance. The present study agrees with those studies as it suggested that female mathematics teachers' instructional practices with digital technology were better male teachers. Furthermore, this study also showed teachers' level of education plays an important role in teachers' instructional practices. This finding is well suited to the view that teachers' education level as a crucial factor to improve teacher quality [see 50]..

Finally, to some extent, lack of Indonesian secondary school mathematics teachers who used digital technologies to facilitate students' knowledge construction. This finding is in agreement with existing studies in other countries, revealing that teachers have not reached a constructive way of technology use [e.g., 36, 37-40]. This might happen due to the fact that Indonesian teachers did not have sufficient technological knowledge as well as knowledge of technology integration in teaching and learning process [See., 41]. Therefore,, the development of teachers knowledge is necessary step that need to take into account in order to improve teachers instructional practices in the use of technologies [42]

\section{Conclusions}

This study showed that the integration of digital technologies in Indonesian secondary school mathematics classrooms has emerged. However, the current practice still leaves a large room for improvement as this study suggests that most of the teachers used digital technology for a very limited number of mathematics lessons. Furthermore, most of the teachers use used presentation-oriented software. As a result, it raised a concern about the impact of the digital technology integration since such digital tools do not offer many advantages for enhancing the teaching and learning of mathematics. To a large extent, the teachers did not integrate the technology in constructive ways to facilitate students' knowledge construction. In addition, this study reveals that female teachers have better instructional practices than male teachers. In addition, teachers' level of education plays an important role in the integration of technologies in mathematics classrooms. Finally, as the integration of technology in the classroom has emerged, we suggest a study to explore the impact of this integration on students' learning outcomes and their experience in learning mathematics with digital technologies.

\section{Acknowledgments}

We would like to thank Asian Centre for Mathematics Education, East China Normal University for financially support the completion of this paper by a research grant from (Project No. 92900-120215-10514). The second author's participation was also in part supported by a research grant from East China Normal University's "Happy Flowers" Strategic Research Fund (Award No: 2019ECNU-XF2H004 ).

\section{REFERENCES}

[1] Mailizar, Manahel A, Fan L. A historical overview of Mathematics curriculum reform and development in modern Indonesia. Teaching Innovations. 2014;27(3).

[2] Berrett B, Murphy J, Sullivan J. Administrator insights and reflections: Technology integration in schools. The Qualitative Report. 2012;17(1):200-21.

[3] Kimmons R, Miller BG, Amador J, Desjardins CD, Hall C. Technology integration coursework and finding meaning in pre-service teachers' reflective practice. Educational Technology Research and Development.2015;63(6):809-29.

[4] Lawless K, Pellegrino J. Professional development in integrating technology into teaching and learning: Knowns, unknowns, and ways to pursue better questions and answers. Review of Educational Research. 2007; 77: 575-614.

[5] Hardman J. Towards a pedagogical model of teaching with ICTs for mathematics attainment in primary school: A review of studies 2008-2018. Heliyon. 2019;5.

[6] Jackson M. Integration of ICT in the Mathematics Classroom. Journal of Initial Teacher Inquiry. 2017; 3:90-3.

[7] Ottenbreit-Leftwich AT, Kopcha TJ, Ertmer PA. Information and Communication Technology Dispositional Factors and Relationship to Information and Communication Technology Practices. Second Handbook of Information Technology in Primary and Secondary Education. 2018:309-33.

[8] Pelgrum WJ, Voogt J. School and teacher factors associated with frequency of ICT use by mathematics teachers: Country comparisons Education and Information Technologies. 2009; 14:293-308.

[9] Law N. Mathematics and science teachers' pedagogical orientations and their use of ICT in teaching. Education and Information Technologies. 2009; 14:309-23. 
[10] Forgasz HJ. Teachers and computers for secondary mathematics. Education and Information Technologies. 2002;7(2):111-25.

[11] Loong E, Doig B, Grove S. How different is it really? - rural and urban primary students' use of ICT in mathematics. Mathematics Education Research Journal. 2011; 23:189-211.

[12] Becker HJ, Ravitz JL, Wong YT. Teacher and teacher-directed student use of computers and software. Irvine: University of California at Irvine, 1999.

[13] Kitchen S, Finch S, Sinclair R. Harnessing technology: School survey 2007. Conventry: National Center for Social Research; 2007.

[14] Bretscher N. Exploring the quantitative and qualitative gap between expectation and implementation: A survey of English mathematics teacher' use of ICT. In: Clark-Wilson A Robutti O, Siclair N, editors. The mathematics teacher in the digital era. New York: Springer; 2014.

[15] Hammond M, Reynolds L, Ingram J. How and why do student teachers use ICT? Journal of Computer Assisted Learning. 2011; 27:191-203.

[16] Law N, Pelgrum WJ, Plomp T, editors. Pedagogy and ICT Use. Hongkong: Comparative Education Research Center, The University of Hongkong; 2008.

[17] Tay LY, Lim SK, Lim CP, Koh JHL. Pedagogical approaches for ICT integration into primary English and mathematics: A singapore case study. Australasian Journal of Educational Technology. 2012;28(4):740-54.

[18] Polly D. Elementary school teachers' use of technology during mathematics teaching. computers in the Schools. 2014; 31:271-92.

[19] Lim CP, Chai CS. Teachers' pedagogical beliefs and their planning and conduct of computer-mediated classroom lessons. British Journal of Educational Technology. 2008; 39:807-28.

[20] Petras CM. A descriptive study of science and mathematics teachers pedagogy, ICT use and perceptions of how ICT impacts their teaching. Malibu, CA: Perperdine University; 2010.

[21] Fraser, Garofalo J. Novice mathematics teacher' use of technology to enhance student engagement, questioning, generalization, and conceptual understanding. Journal of Technology and Teacher Education. 2015;23(1):29-51.

[22] Manoucherhri A. Computer and school mathematics reforms: Implication for mathematics teacher education. Journal of Computers in Mathematics and Science Teaching. 1999;18(1):31-48

[23] Mullis I, Martin M, Foy P. TIMSS 2007 international mathematics report. Boston College: TIMSS \& PIRLS International Study Centre; 2008.

[24] Mullis I, Martin M, Foy P, Arora A. TIMSS 2011 international results in mathematics. Boston College: TIMSS \& PIRLS International Study Centre; 2011.

[25] Comi SA, Argentin G, Gui M, Origo F, Pagani L. Is it the way they use it? Teachers, ICT and student achievement. Economics of Education Review. 2017; 56:24-39.
[26] Pierce R, Stacey K. Mapping pedagogical opportunities provide by mathematics analysis software. international Journal Computer Mathematics Learning. 2010; 15:1-20.

[27] Creswell JW. Research design: Qualitative, quantitative, and mixed methods approaches. Thousand Oaks, California SAGE Publication, Inc; 2009.

[28] Fraenkel JR, Wallen NE. How to design and evaluate research in education Boston: MacGraw-Hill; 2009.

[29] Muijs D. Doing quantitative research in education with SPSS. London: Sage; 2004.

[30] Hohenwarter M, Lavicza Z, editors. Mathematics teacher development with ICT: Towards an international GeoGebra Institute. The British Society for Research into Learning Mathematics; 2007; Northampton.

[31] Ruthven K, Deaney R, Hennessy S. Using graphing software to teach about algebraic forms: A study of technology-supported practice in secondary-school mathematics. Educational studies in mathematics. 2009;71(3):279-97.

[32] Cuban L, Kirkpatrick H, Peck K. High access and low use of technologies in high school classroom: Explaining an apparent paradox. American Educational Research Journal. 2001;38(4):813-34.

[33] Cavanagh M, Mitchelmore M. Learning to teach secondary mathematics using an online learning system. Math Ed Res J. $2011 ; 23: 417-35$.

[34] Thomas M, Monaghan J, Pierce R. Computer algebra systems and algebra: Curriculum, assessment, teaching, and learning. The Future of the Teaching and Learning of Algebra The 12 th ICMI Study. Dordrecht, Netherlands: Springer; 2004. p. 153-86.

[35] Vincent J, editor Year 8 students' reasoning in a Cabri environment. Mathematics education researching: Innovation, networking, opportunity Proceedings of the 26th annual conference of the Mathematics Education Research Group of Australasia; 2003; Geelong, Australia.

[36] Kozma RB. Technology and classroom practices: An international study. Journal of Research on Technology in Education. 2003; 36:1-14.

[37] Mueller J, Wood E, Willoughby T, Ross C, Specht J. Identifying discriminating variable beetween teachers who fully integrate computers and teachers with limited integration. Computers and Education. 2008; 51:1523-37.

[38] Tondeur J, Van Braak J, Valcke M. Towards a typology of computer use in primary education. Journal of Computer Assisted Learning. 2007;23(3):197-206.

[39] Hennessy S, Ruthven K, Brindley S. Teacher perspective on integrating ICT into subject teaching: commitment, constrains, caution, and change. J Curriculum Studies. 2005;37(2):155.

[40] de Aldama C, Pozo JI. How are ICT used in the classroom? A study of teachers' beliefs and uses. Electronic Journal of Research in Educational Psychology. 2016;14(2):253-86.

[41] Mailizar, Fan L. Indonesian teachers' knowledge of ICT and the use of ICT in secondary mathematics teaching. EURASIA Journal of Mathematics, Science and Technology 
Education. 2020;16(1):1-13.

[42] Drossel K, Eickelmann B, Gerick J. Predictors of teachers' use of ICT in school-the relevance of school characteristics, teachers' attitudes and teacher collaboration. Education and Information Technologies. 2017;22(2):551-73.

[43] Panteli N, Stack J, Ramsay H. Gender and professional ethics in the IT industry. Journal of Business Ethics. 1999;22(1):93-101.

[44] Tezci E. Attitude and knowledge level of teachers in ICT use: the case of Turkish teachers. International Journal of Human Science 2010;7(2):19-44.

[45] Vitanova V, Atanasova-Pachemska T, Iliev D, Pachemska S. Factors affecting the development of ICT competencies of teachers in primary schools. Procedia-Social and Behavioral Sciences. 2015; 191:1087-94.

[46] Loyd B, Gressard C. Gender and amount of computer experience of teachers in staff development programs: Effects on computer attitudes and perceptions of the usefulness of computers. AEDS journal. 1986; 19:302-11.

[47] Markauskaite L. Gender issues in preservice teachers' training: ICT literacy and online learning. Australasian Journal of Educational Technology. 2006;22(1):1.

[48] King J, Bond T, Blandford S. An investigation of computer anxiety by gender and grade. Computers in Human behavior. 2002;18(1):69-84

[49] North AS, Noyes JM. Gender influences on children's computer attitudes and cognitions. Computers in Human Behavior. 2002;18(2):135-50.

[50] Zhang D. The effect of teacher education level, teaching experience, and teaching behaviours on students science achievement. Logan, Utah: Utah State University; 2008R. F. Voss, J. Clarke. Algorithmic Musical Composition, Silver Burdett Press, Londyn, 1986. 